

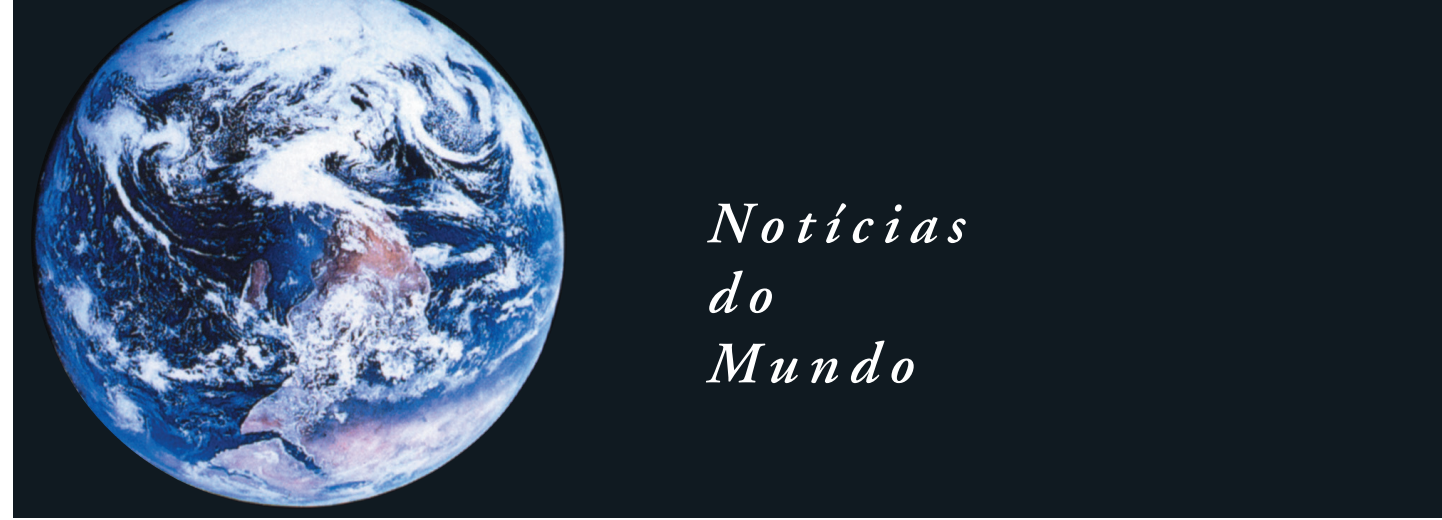

para obtenção do dinheiro para transformar um lugar", compara Gallo.

GUERRA DE LUGARES O tipo de atividade econômica também deve ser considerado. "Creio que o grande capital tem poder de ação na escala das cidades, que pode impor e determinar que tipo de atividade econômica será exercida naquele ponto do planeta. Algumas correntes da geografia chamam isso de especialização funcional dos lugares, capaz de criar sinergias entre as empresas instaladas no lugar $\mathrm{e}, \mathrm{com}$ isso, potencialmente fazer a atividade produtiva florescer", analisa. Porém, caso não ocorra a prosperidade econômica esperada, toda uma cidade pode deixar de ser atraente ao capital e ser abandonada.

"O poder de ação das grandes empresas internacionais na escala dos lugares é muito elevado. O que se tem que levar em conta é que a escolha da implantação de um empreendimento atende uma lógica. Se um dia essa lógica mudar, o lugar originalmente escolhido pode ser abandonado para ser substituído por outro mais atrativo - é o que chamamos, também, de guerra dos lugares", explica.

É difícil traçar o futuro da população que foi obrigada a deixar uma cidade fantasma. "A população pode ter uma redução da qualidade de vida se não conseguir se inserir produtivamente em outro lugar ou pode ter uma melhor qualidade de vida se for para uma cidade que ofereça melhores perspectivas", conta Alves. No mesmo sentido, Gallo concorda que não há como prever tal condição. "Se uma população saiu de um lugar (que deixou de ser atrativo) ela pode ter encontrado condições melhores em outros pontos. Neste caso, o retorno será pouco provável”.

RECUPERAÇÃo AMBIENTAL As cidades fantasma podem ter um lado benéfico. "Do ponto de vista ecocêntrico pode ser um grande avanço para as demais espécies vivas do local. Há vários exemplos de civilizaçóes e cidades que desapareceram e o meio ambiente se recuperou rapidamente dos danos causados pelas atividades antrópicas”. Exemplo disso é Igatu, na Chapada Diamantina (BA), uma cidade fantasma que já foi povoada por garimpeiros e familiares em busca de diamantes, mas hoje é um destino turístico. "O fim das atividades mineradoras foi ótimo para o meio ambiente. Em geral, as atividades de garimpo e mineração degradam muito a natureza. Entretanto, o turismo, se não for bem controlado e planejado, também pode ter impacto degradador. Ecossistemas ricos, como o da Chapada Diamantina, deveriam ficar o mais longe possível dos efeitos deletérios da atividade humana", opina Alves.

\section{Patricia Piacentini}

Reprodução

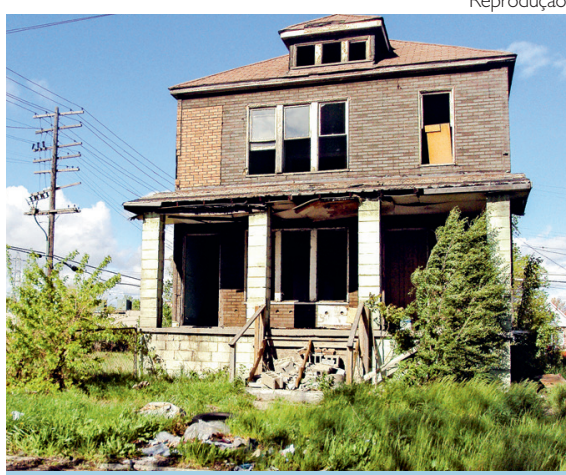

Imóvel abandonado em Detroit

\section{Detroit -}

\section{Procura-SE VIZINHOS!}

Detroit, nos EUA, que já concentrou gigantes da indústria automobilística, como Ford e General Motors, está abandonada. A cidade viveu seu auge durante e logo depois da Segunda Guerra Mundial. Sentiu a decadência nos anos 1970, principalmente pela concorrência com as indústrias japonesas. A hoje falida Detroit viu sua população decair drasticamente e virou um cenário com milhares de imóveis vazios e deteriorados. Tanto o setor industrial como a área residencial foram gradativamente esvaziados. Em 2014, a prefeitura passou a leiloar imóveis com o objetivo de repovoar a cidade. Acesse o site Building Detroit: http://www.buildingdetroit.org 